\title{
Commentaries and the Problem of Authority (with particular attention to editing fragments)
}

Benjamin Millis

Editing and commenting on fragments and fragmentary texts is an often difficult endeavour that has its own problems and concerns intrinsic to the nature of the material, but many of the basic issues are essentially the same as those faced when dealing with any sort of text. Editing texts, and equipping these texts with commentaries of various sorts and levels of complexity, is a very old process that has its roots in antiquity. However much this process may have evolved over the past two millennia or so, the essential activity - producing a text in accord with certain aims (usually increased readability or accuracy) and explicating this text in accord with the needs of a certain imagined readership - has remained much the same. Adherence to a long and successful tradition has doubtless played no small part in the continued vitality of editions and commentaries, but they no longer occupy the same central role in scholarship that they did until well into the modern period. Over the course of the I9th and, particularly, the 2oth centuries, the edition and commentary was eclipsed by the monograph as the prime means of scholarly discourse. As part of this process of a shift in the mode of scholarly expression, commentaries have become viewed much more as an aid to producing advanced scholarship than as advanced scholarship itself.

As commentaries have moved to a more subsidiary role over the past century or so, perception of some fundamental differences between different sorts of commentaries and editions has likewise changed. A distinction between different levels of commentaries and editions, namely between 'shorter' commentaries on the one hand and 'longer' or 'comprehensive' (a debatable term to be discussed below) ones on the

This lecture was given at the Ars edendi workshop on Fragments and Commentaries 27-28 August, 20I5.

How to cite this book chapter:

Millis, B. 2020. Commentaries and the Problem of Authority (with particular attention to editing fragments). In: Kihlman, E. and Searby, D. (eds.). Ars Edendi Lecture Series. vol. V. Pp. I 5-28. Stockholm: Stockholm University Press. DOI: https://doi .org/ıo.16993/bbd.c. License: CC-BY 
other hand, ${ }^{\text {I }}$ is still commonly recognized, although the different uses and aims of the two types, aside from a general feeling that the one is more appropriate for 'advanced' readers or suitable for 'experts' in a given text, appears to be less clearly understood. Similarly fading from common appreciation is the distinction that has aptly been described as 'insular' vs. 'continental'. ${ }^{2}$ As commentaries and editions have become less important in their own right as a vehicle for pushing the bounds of scholarship, differences between the various sorts have become elided, resulting in a much more monolithic conception of what a commentary or an edition is and what it is trying to do. The greater the extent to which commentaries become viewed as all doing essentially the same thing, namely supplying answers to a discrete and limited set of questions, the more the pattern repeats and the less commentaries are seen as interpretative works.

The long-term shift of scholarly production away from editions and commentaries and toward monographs is not necessarily a bad thing in itself; aside from anything else, it is indicative of a laudatory broadening interests toward topics that are perhaps better suited to the flexibility of the monograph. But one clear drawback is an ever narrower conception of what editions and commentaries are meant to

I The distinction here is the one often described as between 'student' and 'scholarly' commentaries. It is true that 'shorter' commentaries are far more frequently used in the classroom and that 'longer' commentaries are largely the preserve of scholars and, to a lesser extent, advanced students, but the line between the two is not always easy to draw. Elementary commentaries aside, 'shorter' commentaries are regularly works of real scholarship despite any aiming at an ostensibly less advanced audience, and the differences tend to lie more in level of detail and style of presentation than in content. The difference between the two sorts of commentaries is brought out well by the comparison on pp. 348-353 in Roy Gibson, 'Fifty Shades of Orange: Cambridge Classical Texts and Commentaries', in Classical Commentaries: Explorations in a Scholarly Genre, ed. by Christina S. Kraus and Christopher Stray (Oxford: Oxford University Press, 20I6), pp. 346-375.

2 See M. L. West, 'Forward into the Past', in Hesperos: Studies in Ancient Greek Poetry Presented to M. L. West on his Seventieth Birthday, ed. P. J. Finglass, C. Collard and N. J. Richardson (Oxford: Oxford University Press, 2007), pp. $\mathrm{xx}-\mathrm{xxviii}$, where West relates on p. xxiv an anecdote in which he was asked by Stefan Weinstock which of the two sorts he (West) was writing. West goes on to define the distinction as 'the sort of commentary that seeks only to elucidate the particular work which is its object, or the sort that reaches out in all directions and is full of material relevant to other authors in which related things occur.' The formulation 'insular' vs. 'continental', particularly in the mouth of a refugee German scholar, might suggest a dig at British scholarship, but West does not suggest any such implication in his account. 
accomplish, to whom they are directed, and how they fit with other scholarship in the field. ${ }^{3}$ Seemingly one of the most common misconceptions about commentaries is that there is an essentially finite series of questions that a commentary on a given text attempts to answer and that the fundamental difference between commentaries is the greater or lesser level of nuance and detail given in providing these answers. In accord with this view, the basic questions about a text are already largely known and once these have been addressed as best as possible by restoring the text as closely as possible to what the author wrote, or is believed to have written, and by explicating the content (linguistic, stylistic, literary, etc.) to an appropriate degree, the editor's job is done. Of course this view of the texts themselves, and of what editors do, is overly simplistic and notably stands in stark contrast with how texts are understood by scholars working, for example, on literary analysis; it is, nonetheless, a perception seemingly widely held by the field at large, including by many editors and commentators themselves. One indication of this is the idea of a 'standard' edition, by which is too often meant 'definitive', or at least 'definitive for our time', and the pernicious effect that this concept can have on scholarship. Once a commentary sufficiently detailed has been written on a given work, the general consensus commonly arises that that work has been 'done', leaving no room or point to producing another; further work along these lines is not just discouraged but usually never even considered, at least until enough time has passed. ${ }^{4}$ In contrast, monographs that provide a literary analysis of a particular work, for example, seem not to be held to the same strictures, i.e. monographs seem somehow distinct from one another in a way that commentaries are not. The same is also true for translations; they also apparently seem individualistic enough

3 For brief comments about discrepancies between the intentions of commentary writers and the expectations of commentary readers, see Gibson, pp. 366-367.

${ }_{4}$ For much the same observation, see Gibson, p. 365. He goes on to note, à propos of F. R. D. Goodyear, The Annals of Tacitus, vol. I: Annals I.I-54 (Cambridge: Cambridge University Press, I972) and The Annals of Tacitus, vol. II: Annals I.55-8I and Annals 2 (Cambridge: Cambridge University Press, I98I), 'But who - at least in English - would take on Annals I again at such length, despite the widely perceived deficiencies in Goodyear's editions? (And what press would publish such a commentary?)' Although 'competing' commentaries do occasionally appear, and Gibson cites one such example, this is very much the exception; overwhelmingly more common is the avoidance of 'duplication', even in cases like that of Goodyear's Tacitus which is both nearly half a century old and not unproblematic. 
that 'competing' translations are generally seen as a positive rather than as something to be avoided.

One factor seldom remarked on, yet among the most important, at least for Anglo-American scholarship, is the effect that Eduard Fraenkel's edition of Aeschylus, Agamemnon has had in shaping subsequent scholarship. ${ }^{5}$ Fraenkel's immense personal authority combined with the utterly impressive philological achievement of his commentary, largely unparalleled in effect, ${ }^{6}$ to establish a template for what a scholarly commentary on an ancient text could be and perhaps even should be. ${ }^{7}$ There is no particular reason to believe that Fraenkel had any doubts whatsoever about the excellence of his commentary, but there is also no reason to believe that he anticipated the status his commentary

5 Eduard Fraenkel, Aeschylus, Agamemnon (Oxford: Clarendon Press, 1950).

${ }^{6}$ Fraenkel's commentary is not entirely without parallel, in that a number of the older variorum commentaries can compare with it in terms in scope if not in learning, but almost the only really comparable works in terms of both breadth and erudition are a handful of the commentaries produced by the leading scholars of the 17 th and I 8 th centuries. There are also a number of works that are comparable in scope and erudition and very closely contemporary, i.e. Rudolf Pfeiffer, Callimachus (Oxford: Clarendon Press, I949-I953), Felix Jacoby's work on the Atthidographers (Atthis: The Local Chronicles of Ancient Athens [Oxford: Clarendon Press, 1949], Die Fragmente der griechischen Historiker III B [Leiden: E. J. Brill, I950] and Die Fragmente der griechischen Historiker III b (Supplement) [Leiden: E. J. Brill, I954]) and A. S. F. Gow, Theocritus (Cambridge: Cambridge University Press, I950); note that the one work not produced by a German exile was also the only one not produced at Oxford. But for all the virtues, tremendous learning and influence of these other works, their dominance has not been quite as long lasting nor have they occupied quite the same place in the imagination as a scholarly exemplar. The obvious comparison is of course Ulrich von Wilamowitz-Moellendorff, Euripides, Herakles (Berlin: Weidmann, I889 [2nd ed. I 895]) (cf. p. 44 n. I 2 in Christopher Stray, 'A Teutonic Monster in Oxford: The Making of Fraenkel's Agamemnon', in Classical Commentaries: Explorations in a Scholarly Genre, ed. by Christina S. Kraus and Christopher Stray (Oxford: Oxford University Press, 2016), pp. 39-57), but for all its tremendous influence and learning, Wilamowitz' commentary is a very different work and never became the exemplar that I am suggesting Fraenkel's work did.

7 For a recent account of Fraenkel's Agamemnon, see Stray, 'Teutonic Monster'; cf. Jaś Elsner, 'Pfeiffer, Fraenkel, and Refugee Scholarship in Oxford during and after the Second World War', in Ark of Civilization: Refugee Scholars and Oxford University 1930-1945, ed. by Sally Crawford, Katharina Ulmschneider and Jaś Elsner (Oxford: Oxford University Press, 2017), pp. 25-49. For Fraenkel the man, the basic account is Gordon Williams, 'Eduard Fraenkel I888-1970', Proceedings of the British Academy 56 (I970) 4I 5-442; most recently, see Christopher Stray, 'Eduard Fraenkel (I888-1970)', in Ark of Civilization: Refugee Scholars and Oxford University I930-I945, ed. by Sally Crawford, Katharina Ulmschneider and Jaś Elsner (Oxford: Oxford University Press, 20I7), pp. I80-I97 (with all essential bibliography). 
would eventually achieve, and indeed he is fairly explicit that he saw his task largely as clearing away masses of accumulated error and highlighting real insights and important work in order to promote further scholarship, not to forestall it. ${ }^{8}$ Regardless of Fraenkel's own intentions and despite some discomfort from others at the time that Fraenkel's views might prove overly dominating, ${ }^{9}$ the lesson that many seem to have taken away from Fraenkel's work was that aside from details here and there he had said the last word on the play, at least for the foreseeable future. Contemporaries influenced by Fraenkel, but to a much greater extent his students, and the students of his students, absorbed this idea of a monumental, definitive commentary and took this as a model for their own work. ${ }^{\text {Io }}$ The essential idea seems to be that if one is diligent enough and does one's work properly, there would be little left to say, thus rendering other attempts largely superfluous. In any case, the concept of the standard commentary, so prevalent by the end of the twentieth century, is completely foreign to the model that prevailed at the outset of the century, when for example in the twenty-five years spanning the turn of the nineteenth to twentieth centuries no less than six or eight new editions of Acharnians were produced, and this number could be increased still further if revised editions of older work were also taken into account. ${ }^{\text {II }}$

${ }^{8}$ See Fraenkel, pp. vii-ix.

9 See, for example, E. R. Dodds as quoted at Stray 'Teutonic Monster', p. 54: 'it is not good that any book, however outstanding, should acquire the status of an oracle.'

10 For the claim that Fraenkel 'decisively influenced the whole approach to the study of Classical antiquity in Britain' and for a general overview of his influence, see Williams pp. 422-423. Contrast John Dewar Denniston and Denys Page, Aeschylus, Agamemnon (Oxford: Clarendon Press, I957), p. iv, where Page assumes that the commentary by Denniston and himself and that by Fraenkel are merely two points on a long continuum that stretches into the past but also the future; Page's implication is that a commentary on a scale similar to his own would appear not so far in the future, but sixty years later that has yet to happen.

II Editions of Acharnians published in this period include the following: Frederick H. M. Blaydes, Aristophanis Acharnenses (Halle an der Saale: Waisenhaus, I 887); J. van Leeuwen, Aristophanis Acharnenses (Leiden: A. W. Sijthoff, I90I); W. Rennie, The Acharnians of Aristophanes (London: Edward Arnold, I909); W. J. M. Starkie, The Acharnians of Aristophanes (London: Macmillan, I909); Benjamin Bickley Rogers, The Acharnians of Aristophanes (London: George Bell \& Sons, I9ro); Richard Thomas Elliott, The Acharnians of Aristophanes (Oxford: Clarendon Press, I9I4). The above list includes only substantial editions that contain both text and commentary and that were first published within this narrow window; the list could be expanded by including school editions, editions of texts without commentary and subsequent editions of works published earlier. Lest the example of Acharnians give the appearance of being an extreme case, the situation is not far 
The reason for going through all this at such length is not to criticize any particular commentary or scholar but to try to encourage greater reflection on what writing a commentary is meant to accomplish and on the place of editions and commentaries in modern scholarship more generally. There is of course no single answer to this question, and that fact is indeed part of the answer. Editions and commentaries form an important, in fact crucial, mediating role between texts and so-called higher criticism and in making texts accessible, in the widest sense of the word, to scholars of every sort. But beyond this, and what is often forgotten, editions and commentaries are not solely a sort of middle point in this way but are also themselves a dialogue with the material and a grappling with it much like any other type of criticism or analysis. As such, it is perhaps worthwhile that they be re-legitimized as an end in themselves, not simply as a means to an end. What this means in practical terms is that editions and commentaries should be viewed as interpretative works like any other, rather than solely as reference works answering a circumscribed set of questions, and that any notion of a standard or definitive edition be largely abandoned.

Turning to editing and commenting on fragments in particular, editions of fragments tend, on the one hand, to reinforce this notion of the one authoritative edition in that such editions appear seldom, and only rarely more than once in a generation or so. While this is natural enough, given that fragments are often on the margins of mainstream work, editions of fragments can, on the other hand, work against this trend and help to re-legitimize editions and commentaries as a means of engaging with texts as valid as any other, largely because the nature of fragments is such that often they are best handled via commentaries.

In his commentary on the Agamemnon, Fraenkel was explicit that his commentary and its structure was informed by the need to sift through vast amounts of bibliography in order to root out entrenched, but mistaken, ideas and to resurrect illuminating insights that had been forgotten or overlooked. This process is of course a large part of writing any scholarly commentary, although perhaps relatively few have plumbed the depths of previous scholarship to the extent that Fraenkel did, even if complaints in prefaces about mountains of bibliography are something of a trope. But in the case of fragments, the situation is reversed, and it is very often possible to control the bibliography in its

different for several other plays of Aristophanes, numerous tragedies and a variety of other popular texts both Greek and Latin. 
entirety if one so desires. The danger in this possibility lies in the fact that an editor is not forced to be ruthlessly selective and so the exercise of critical judgement can easily be side-lined as a range of views are presented as if they are all equally valid. Since the amount of previous work is usually so limited, the temptation to discuss it all and to take it all seriously is strong. In reality, simply because a suggestion is one of a handful instead of one of many does not mean it is necessarily more worthy of discussion. A related issue involves the interpretation of difficult passages. In extant works, particularly those that have been studied repeatedly and in detail for centuries, the basic interpretational possibilities of difficult passages have often been long known, and thus in practice, interpretation can frequently consist of picking from one of a number of opposing viewpoints. In the case of fragments, following this same procedure is a trap that is easy to fall into, but in fact it not infrequently transpires that the best interpretation of a particular passage is one that has not yet been suggested.

Obedience to authority and the great name is a problem in all walks of life, but particularly for the editor of texts, and among editors of tests especially for the editor of fragments. The material is difficult, in most cases only a handful of scholars have worked on it, and this handful often includes some of the greatest names in the history of the field. The temptation to follow them uncritically is easy to give in to, especially when few alternatives have been suggested, but must be avoided. Scholars like Casaubon or Bentley may well be right more often than they are wrong, but that does mean they are incapable of blunders or even stupidity; scholars like van Herwerden or Blaydes may overwhelm their shrewd suggestions with oceans of wild conjectures, but that does not mean their views should necessarily be treated with contempt. Every suggestion should be judged on its own merits regardless of its author; as a piece of advice, this is an old chestnut of seemingly obvious truth, but practice has repeatedly shown that its application is not as easy as it sounds. ${ }^{12} \mathrm{~A}$ case in point is the dating of a number of minor comic poets. The chronology of the Greek comic poets generally, as we understand it today, is largely the work of August Meineke together with some minor modifications resulting from epigraphical discoveries

${ }^{12}$ See R. D. Dawe, Repertory of Conjectures on Aeschylus (Leiden: E. J. Brill, I965), pp. 4-7; cf. N. G. Wilson, Aristophanes Fabulae, vol. I (Oxford: Clarendon Press, 2007), p. viii. 
of the late nineteenth century. ${ }^{13}$ Meineke judged that a number of poets could not be dated, and a number of others he dated to late in the Hellenistic period. With very few exceptions, this same chronology has been followed uncritically by all subsequent editors, including the justly lauded Kassel and Austin, even in cases where investigation and attention to detail shows that the received dates are almost certainly wrong. ${ }^{14}$ One strongly suspects that had these dates been suggested not by Meineke, but instead by Kock or Edmonds, the evidence for these dates would have been examined far more carefully and the dates themselves not just argued against but actively ridiculed.

At least as insidious and liable to unthinking obeisance to authority is the issue of presentation and ordering of fragments. Most scholars tend, reasonably enough, to favour inertia and the retention of inherited ordering in the absence of a compelling reason for change. But the ordering of fragments, even when superficially innocuous, has a very real effect on how fragments are understood both individually and in relation to one another and can drive interpretation in directions that are unwarranted. ${ }^{15}$ A good example is the three fragments of the play Agroikoi (Rustics) by the comic poet Anaxandrides. These three fragments, all preserved by Athenaeus, were arranged by Meineke and earlier scholars, and thus also by all subsequent editors, in an order that does not reflect their occurrence in Athenaeus but that does seem to form a narrative. The fragments refer respectively to participation in a symposium, a description a previous feast or symposium, and a recollection of heavy drinking. This sequence has often been taken as informing our understanding of the structure of the play: a rustic

${ }^{13}$ Meineke presented his chronological conclusions, together with much of the evidence, as Fragmenta Comicorum Graecorum, vol. I: Historia Critica Comicorum Graecorum (Berlin: Reimer, I 839); these results of course provided the overarching structure for the remainder of his edition of the comic fragments (as for all subsequent editions aside from that by Kassel-Austin who sensibly used alphabetic order).

${ }^{14}$ For some examples, see Benjamin Millis, 'Post-Menandrian Comic Poets: An Overview of the Evidence and a Checklist', in The Oxford Handbook of Greek and Roman Comedy, ed. by Michael Fontaine and Adele Scafuro (New York: Oxford University Press, 20I4), pp. 87I-884.

Is Jackie Elliott, 'Commenting on Fragments: The case of Ennius' Annales', in Classical Commentaries: Explorations in a Scholarly Genre, ed. by Christina S. Kraus and Christopher Stray (Oxford: Oxford University Press, 2016), pp. I36-I56 has a good discussion of some of the issues and interpretive problems that can result even from an entirely reasonable organization of fragments as well as thoughtful consideration of a number of other issues that arise when editing fragments. 
participates in a symposium, later in the play he looks back to it and describes it to someone and then in the same or a later scene also discusses the effect the drinking had on him, possibly realizing that city life is not for him. This interpretative sequence appears to make sense and is superficially attractive. But one main stumbling block is that the same series of events is thus both acted out on stage (fr. I) and related, apparently in some detail, in a narrative description (fr. 2). Since this is inherently unlikely, the standard interpretation that links the three fragments in a clear narrative sequence is almost certainly incorrect and obviously so; ordering of the fragments so as to suggest this interpretation, and then retaining this order in obedience to tradition, has worked mainly to reinforce for centuries an unlikely interpretation. ${ }^{\mathrm{I}}{ }^{6}$

These three fragments also incidentally exemplify a related pitfall to be guarded against constantly, namely the compulsion to take the meagre snippets of information that survive and try to combine them into a coherent narrative. Attempting to reconstruct the plots of lost plays, a path that is easy to be tempted onto and difficult to withstand, has traditionally formed a large part of work on fragments yet has served in many ways more to obscure difficulties than to elucidate real problems. While it is true that a group of fragments that seems to form a coherent narrative sequence could reflect in some way the overall structure of a work with reasonable accuracy, it is at least as likely that either such a sequence comes from a single scene that has no larger structural significance or the sequence is in fact illusory and is composed of fragments that belong to widely divergent parts of a work and thus have no real relation to one another in terms of plot. The fact of the matter is that being able to shoe-horn most, if not all, fragments of a given play into an intelligible sequence with structural significance for the plot is no guarantee that such an interpretation is correct and, somewhat counter-intuitively, the more loose ends that can be absorbed, the less likely the over-all interpretation is likely to be true. ${ }^{17}$

${ }^{16}$ For discussion of the relationship between the three fragments, see Benjamin Millis, Anaxandrides (Heidelberg: Verlag Antike, 2015), p. 35 (pp. 36-48 for the fragments themselves in greater detail); the traditional order of the fragments was retained there also, although a better decision would have been to print them in the order in which they appear in Athenaeus.

${ }_{17}$ This issue has come much more to fore recently, particularly in the work of S. Douglas Olson, e.g. 'Athenaeus' Aristophanes and the Problem of Reconstructing Lost Comedies', in Fragmente einer Geschichte der griechischen Komödie / Fragmentary History of Greek Comedy, ed. by Stylianos Chronopoulos and Christian Orth (Heidelberg: Verlag Antike, 201 5), pp. 35-65 (see esp. pp. 47-48); 
A third issue, perhaps the most difficult of all, that the editor of fragments faces is the trustworthiness of his sources. We normally have such little information that any pointer given by an ancient source is grasped with the alacrity of a drowning man seizing a raft. The problem is that sources can be misleading, are only as good as their sources, and can even actively misrepresent what little knowledge they actually have. A good example is the quotation of several comic fragments in the twenty-eighth oration of Aelius Aristides. Aristides quotes two lines from a comic poet, noting that they came from the beginning of the play, presumably meaning the prologue. He then goes on to quote another line that he says came from the end of the poet's play Cheirons. ${ }^{18}$ Aristides' phrasing implies that the two quotations probably came from different plays, although that is perhaps not quite certain, but clearly seems to indicate that both quotations belong to the same poet. We thus have here what appears to be specific and exceedingly valuable information concerning the placement of several quotations within a play or plays by a learned, well-connected, major cultural figure who lived at a time when Greek theatre was probably still a living phenomenon and when copies of plays by various authors should have still been available, at least for someone with the right connections. Unfortunately, this seemingly invaluable information begins to fall apart as soon as it is examined at all closely. First, both the metre and the content of Aristides' first quotation dictate that it must belong not to a prologue or elsewhere near the beginning of a play, but to the parabasis; any other conclusion is contrary to everything we know about such things. Perhaps even more seriously, while the second quotation seems to be convincingly attributed to Cratinus' Cheirons on the basis of the title, a marginal note informs us that the first quotation actually comes from Eupolis' Marikas. The most plausible explanation for at least part of Aristides' confusion is that he had no first-hand knowledge of the plays at all, despite his implication to that effect, but instead was working from an anthology of some sort from which a lemma had fallen out, thus enabling the conflation of quotations from two different plays by two different authors. Also worth noting is that Aristides, and thus presumably his audience, had difficulty distinguishing a prologue from a parabasis. In this particular case, we are fortunate in having information that allows us to check Aristides'

cf. 'On the Fragments of Eupolis' Taxiarchoi', in Studi sulla commedia attica, ed. by Matteo Taufer (Freiburg im Breisgau: Rombach, 20I5), pp. 20I-2I3 (see esp. pp. 207-209).

${ }_{18}$ The two fragments are in fact Eup. fr. 205 and Cratin. fr. 255 respectively. 
assertions; in the vast majority of cases where we have no such information, similar errors must lurk, but we have no means of identifying them. Perhaps even more worrying is that bad information is presented with absolute assurance, and derivative knowledge is presented as if it were the result of first-hand acquaintance with ancient texts.

A common theme linking the first part of my paper, dealing with commentaries more generally, and the second part, looking a few specific problems more closely aligned with editing fragments, is the problem of authority, both ancient and modern, and the pressures one faces from it. It is very difficult to break away from these pressures, which tend to drive interpretation, define the scope of the work, and determine the approach taken. As a result, commentaries can often be reactive, that is responding largely to a set of traditional questions or adhering to a normalized approach. For example, the language of Sophocles or Euripides is not necessarily more interesting or worthy of study than that of Thucydides or Plato, but the traditions of commenting that have developed, particularly over the twentieth century, mean that such investigations are largely side-lined in the case of historians and other prose authors. ${ }^{19}$ This in turn has meant a narrowing of approach to many authors. Although it is not often explicitly acknowledged, editions and commentaries wield enormous power not only in setting the agenda for what sorts of questions are asked of authors but even for what authors are studied at all seriously. It is thus incredibly important that commentators make every effort not to be led by their predecessors but also to move away from the idea of the 'standard' commentary, since this implies that there is a circumscribed number of questions to be dealt with and only one valid approach.

Good commentaries are in many ways about asking questions of the text and expanding the ways of looking at both individual problems and a text as a whole. In this regard, some of the most exciting commentary work being done today is on fragmentary texts because the model of how to write a commentary on such texts is still changing and being developed and so has not ossified into a set approach. The edition and commentary as a form of scholarly engagement with ancient texts has a very long history, has led to great advances in knowledge, and still has much potential. At the same time, it requires much imagination,

${ }^{19}$ For a sketch of the development and norms of commenting on historical texts, see John Davies, 'The Historical Commentary', in Classical Commentaries: Explorations in a Scholarly Genre, ed. by Christina S. Kraus and Christopher Stray (Oxford: Oxford University Press, 2016), pp. 233-249. 
a wide range of skills, and the sort of detailed engagement with the text that is seemingly less and less stressed and valued. Commentators must in many ways strive to be all things to all people, but in doing so we must not lose sight of the real goal, which is furthering knowledge and breathing new life into ancient texts. For many of the problems we face, there is no right answer, or rather no single right answer, and that is why we must constantly examine what we are doing and what we hope to accomplish and, at the same time, allow for a multitude of approaches and aims.

\section{Bibliography}

Blaydes, Frederick H. M., Aristophanis Acharnenses (Halle an der Saale: Waisenhaus, I 887).

Davies, John, 'The Historical Commentary', in Classical Commentaries: Explorations in a Scholarly Genre, ed. by Christina S. Kraus and Christopher Stray (Oxford: Oxford University Press, 2016), pp. 233-249.

Dawe, R. D., Repertory of Conjectures on Aeschylus (Leiden: E. J. Brill, I965).

Denniston, John Dewar and Denys Page, Aeschylus, Agamemnon (Oxford: Clarendon Press, I957).

Elliott, Jackie, 'Commenting on Fragments: The case of Ennius' Annales', in Classical Commentaries: Explorations in a Scholarly Genre, ed. by Christina S. Kraus and Christopher Stray (Oxford: Oxford University Press, 20I6), pp. $136-156$.

Elliott, Richard Thomas, The Acharnians of Aristophanes (Oxford: Clarendon Press, I9I4).

Elsner, Jaś, 'Pfeiffer, Fraenkel, and Refugee Scholarship in Oxford during and after the Second World War', in Ark of Civilization: Refugee Scholars and Oxford University $1930-1945$, ed. by Sally Crawford, Katharina Ulmschneider and Jaś Elsner (Oxford: Oxford University Press, 20I7), pp. 25-49.

Fraenkel, Eduard, Aeschylus, Agamemnon (Oxford: Clarendon Press, I950).

Gibson, Roy, 'Fifty Shades of Orange: Cambridge Classical Texts and Commentaries', in Classical Commentaries: Explorations in a Scholarly Genre, ed. by Christina S. Kraus and Christopher Stray (Oxford: Oxford University Press, 2016), pp. 346-375.

Goodyear, F. R. D., The Annals of Tacitus, vol. I: Annals I.I-54 (Cambridge: Cambridge University Press, I972).

Goodyear, F. R. D., The Annals of Tacitus, vol. II: Annals I.55-8I and Annals 2 (Cambridge: Cambridge University Press, I98I). 
Gow, A. S. F., Theocritus (Cambridge: Cambridge University Press, I950).

Jacoby, Felix, Atthis: The Local Chronicles of Ancient Athens (Oxford: Clarendon Press, I949).

Jacoby, Felix, Die Fragmente der griechischen Historiker III B (Leiden: E. J. Brill, I950).

Jacoby, Felix, Die Fragmente der griechischen Historiker III b (Supplement) (Leiden: E. J. Brill, I954).

Leeuwen, J. van, Aristophanis Acharnenses (Leiden: A. W. Sijthoff, I90I).

Meineke, August, Fragmenta Comicorum Graecorum, vol. I: Historia Critica Comicorum Graecorum (Berlin: Reimer, I839).

Millis, Benjamin, 'Post-Menandrian Comic Poets: An Overview of the Evidence and a Checklist', in The Oxford Handbook of Greek and Roman Comedy, ed. by Michael Fontaine and Adele Scafuro (New York: Oxford University Press, 20I4), pp. 87I-884.

Millis, Benjamin, Anaxandrides (Heidelberg: Verlag Antike, 20 I 5 ).

Olson, S. Douglas, 'Athenaeus’ Aristophanes and the Problem of Reconstructing Lost Comedies', in Fragmente einer Geschichte der griechischen Komödie / Fragmentary History of Greek Comedy, ed. by Stylianos Chronopoulos and Christian Orth (Heidelberg: Verlag Antike, 20I 5), pp. 35-65.

Olson, S. Douglas, 'On the Fragments of Eupolis' Taxiarchoi', in Studi sulla commedia attica, ed. by Matteo Taufer (Freiburg im Breisgau: Rombach, 2OI 5 ), pp. 2OI-2I3.

Pfeiffer, Rudolf, Callimachus (Oxford: Clarendon Press, I949-I953).

Rennie, W., The Acharnians of Aristophanes (London: Edward Arnold, I909).

Rogers, Benjamin Bickley, The Acharnians of Aristophanes (London: George Bell \& Sons, I910).

Starkie, W. J. M., The Acharnians of Aristophanes (London: Macmillan, I909).

Stray, Christopher, 'A Teutonic Monster in Oxford: The Making of Fraenkel's Agamemnon', in Classical Commentaries: Explorations in a Scholarly Genre, ed. by Christina S. Kraus and Christopher Stray (Oxford: Oxford University Press, 2016), pp. 39-57.

Stray, Christopher, 'Eduard Fraenkel (i 888-1970)', in Ark of Civilization: Refugee Scholars and Oxford University I930-I945, ed. by Sally Crawford, Katharina Ulmschneider and Jaś Elsner (Oxford: Oxford University Press, 20I7), pp. I80-I97.

West, M. L., 'Forward into the Past', in Hesperos: Studies in Ancient Greek Poetry Presented to M. L. West on his Seventieth Birthday, ed. P. J. Finglass, 
C. Collard and N. J. Richardson (Oxford: Oxford University Press, 2007), pp. $\mathrm{xx}-\mathrm{xxviii}$.

Wilamowitz-Moellendorff, Ulrich von, Euripides, Herakles (Berlin: Weidmann, I889 [2nd ed. I 895]).

Williams, Gordon, 'Eduard Fraenkel ı 888-1970', Proceedings of the British Academy 56 (I970) 4I 5-442.

Wilson, N. G., Aristophanes Fabulae, vol. I (Oxford: Clarendon Press, 2007). 